\section{Blurring Gender Lines in Readers' Advisory for Young Adults}

\author{
Beth M. Brendler, Guest Columnist \\ Beth M. Brendler, is Assistant Professor at the \\ School of Information Science and Learning \\ Technologies at the University of Missouri.
}

Correspondence to this column should be addressed to Laurel Tarulli, Dalhousie University, School of Information Management, Halifax, Nova Scotia; email: laureltarulli@yahoo.com.
Literacy behaviors that we used to think were gendered are crossing genders now. Whether it is due to changes in gender expectations or changes in how writers are addressing teen readers, we are seeing boys who exhibit literacy behaviors that have been associated with girls and vice versa. In this article, Beth Brendler explores the shift in reading behaviors among girls and boys, reflecting on many examples of current, popular fiction to provide examples of books that cross gender lines. Brendler draws on her past experience as a practicing librarian and head of the youth services department at a public library in Wisconsin. Her teaching interests include youth services in libraries, literacy education, children's literature, and adolescent literature.-Editor

$\mathrm{H}$ ow often do you hear both children and adults refer to texts as "boy books" or "girl books"? Thinking of literature in those terms is the result of early research on gender and literacy. ${ }^{1}$ About forty years ago, in the light of concerns about girls being overlooked in the classroom, researchers began to examine the ways males and females took up literature. Now the concerns are about a literacy gender gap that leaves boys behind. Both issues have asked educators and researchers to look at reading as a gendered practice.

Literacy has been gendered based on the cultural expectations of males and females in our society, and literacy practices have been studied through the lens of those cultural assumptions. Early researchers in gender and literacy reported that children thought in terms of "girl books" and "boy books" and that girls tended to respond to texts via their emotions and feelings about the characters in books, while boys connected to what the characters did in the story. ${ }^{2}$ They found that females were more focused on the relationships and romantic elements in a text, and males were more drawn to action and adventure. ${ }^{3}$ Girls were thought to be more likely to enjoy fiction, particularly realistic fiction that depicts relationships and employs strong character development, while boys often chose to read fiction with action or humor over books that emphasize relationships between characters. ${ }^{4}$ Boys were more likely to enjoy graphic novels, nonfiction, and digital media than girls. ${ }^{5}$ In addition, research indicated that children and teens preferred protagonists that are of the same gender as the reader. ${ }^{6}$

While those studies were enlightening and contributed much to the field of literacy, there have been societal changes over the last few decades that have affected gender beliefs. Research shows that men and women display increasingly less differentiation in their sex role attitudes. ${ }^{7}$ The Millennial 


\section{READERS' ADVISORY}

generation, born between 1980 and 2000, has been viewed as more "inclusive, empathetic and tolerant in their social outlook." This has paved the way for many of today's teenagers to reject the idea of gender as a determinant of societal roles.

While we will still encounter readers with more traditional preferences, much of our teen clientele may have new attitudes toward what they prefer to read. The key to improving readers' advisory is to approach every reader as an individual, recognizing that there is as much diversity within gender as across genders.

\section{YOUNG ADULT FICTION THAT DEFIES GENDER RULES}

This gender diversity is evident in the popularity of some types of adolescent literature. We are seeing more fiction that appeals to both genders. New offerings often combine action/ adventure with romance, paranormal, fantasy, and science fiction elements. Twenty-two of the twenty-eight nominations for 2013 Teens' Top Ten Titles were either fantasy or science fiction, long considered male genres. ${ }^{9}$ These books usually have central characters of both genders. We are seeing more intelligent, capable, athletic heroines; however, they rarely stand alone. There are usually one or two male characters that provide motivation and conflict for the female protagonist. Three examples of this are Kristin Cashore's Graceling (HMH Books for Young Readers, 2008), Veronica Roth's Divergent series, and Suzanne Collins' Hunger Games trilogy, all of which incorporate a strong heroine, science fiction or fantasy, action, and romance.

\section{Contemporary Issues}

The plethora of dystopian and post-apocalyptic novels currently in publication is indicative of adolescents' uncertainty about the future. The readers' advisory website Goodreads lists more than 1,400 books under the heading "Popular YA Post Apocalyptic Books." ${ }^{10}$ The same website lists more than a thousand entries when searched using the phrase "YA dystopian books." The increased interest in speculative fiction is directly related to its topics that graze the surface of reality in a way that hits home with teens who are beginning to question the decisions of established authority. Young adult author Scott Westerfield explains the popularity of dystopian fiction among adolescents:

Teenagers' lives are constantly defined by rules, and in response they construct their identities through necessary confrontations with authority, large and small. Imagining a world in which those authorities must be destroyed by any means necessary is one way of expanding that game. Imagining a world in which those authorities are utterly gone is another. ${ }^{11}$

The oldest of the adolescent audience were only five when our world was rocked by the events of September 11, 2001. It is telling that many of the dystopian stories are set in a United States of a different time. These books reflect issues this generation of teens have always faced, including concern about global environmental disasters, justice and individuality in an increasingly monitored world, social and mind control, technological advances and questions about what it means to be human, morality, terrorism, and the specter of war.

These texts force readers to examine themselves and question their potential responses to circumstances that seem very possible given our current global trajectory, yet they can ask those "what if" questions within the safety of their own world. The protagonists are dealing with very real ethical issues, such as whether it is ever moral to kill another human being or steal from others to survive, when civil disobedience is necessary, and will they be able to stand alone against an immoral society rather than acquiesce to corruption.

Surveillance and voyeurism are common themes. In the Hunger Games trilogy, the characters are in a panopticon, aware that they are being observed but never knowing when. In M. T. Anderson's Feed (Candlewick, 2004), the characters have electronic feeds implanted in their brains that monitor their thoughts and incite their need to follow every consumer trend. In the Divergent series, the characters are injected with a serum that tracks them so the government can always keep them under surveillance.

More books and series are looking at government control, such as the Hunger Games, Divergent, Lauren Oliver's Delirium (HarperCollins, 2011), and Ally Condie's Matched (Dutton Juvenile, 2010). Several of these novels are reminiscent of Lois Lowry's The Giver (Houghton Mifflin, 1993), one of the early YA dystopias. The bestselling Divergent series takes place in a Chicago of the future, where society is divided into five factions, each connected to a specific virtue. There is no discrimination based on race or sexual orientation, which, in comparison with our society, initially makes the setting seem more evolved. At age sixteen, the populace must choose which virtue they will follow. This may mean separation from their families. New faction members are sent to a compound for a three-phase initiation. Initiates are placed in a simulated environment that forces them to face all their deepest fears. Eventually, circumstances force the protagonist to attempt an escape. These novels contain romance, but they are more focused on suspense, conflict, action, and rebellion.

The post-apocalyptic books often begin with a global environmental disaster or in the aftermath of war. Mike Mullin's Ashfall (Tanglewood, 2011) takes place after a super volcano erupts in Yellowstone Park, covering the world in ash and causing pervasive fear and starvation. In Emmy Laybourne's Monument 14 (Feiwel \& Friends, 2012), another massive volcanic eruption is the catalyst for weather anomalies that force a group of teens and children to take shelter and try to survive in a warehouse store. Global warming has spawned a super hurricane that hits the United States, forcing three teens to fight for survival, in Suzanne Weyn's Empty (Scholastic, 2010).

In a setting where the United States has become a militant 
republic, June, a member of the elite, is searching for her brother's murderer. Day, a product of the underclass, is the main suspect. In Marie Lu's Legend (Putnam Juvenile, 2011), June is looking for revenge and Day is trying to survive, but they are both victims of a corrupt government. In Rick Yancey's The 5th Wave (Putnam Juvenile, 2013), the United States has suffered four waves of attacks by aliens. Among the few remaining survivors are Cassie and Ben, high school classmates who have had to transform from carefree teens into military-style leaders to fight the fifth wave of attacks. Daniel Kraus in Booklist describes it as "part War of the Worlds, part Starship Troopers, part Invasion of the Body Snatchers, and part The Stand." ${ }^{2}$ It is clear that this is a novel that will attract teen readers in droves, regardless of gender.

Steampunk novels, a subgenre of speculative fiction that is becoming more popular with teens, are usually set in a post-apocalyptic alternative world that resembles nineteenthcentury England or the western United States. There is some form of steam-powered machinery involved. Catherine Fisher's Incarceron (Dial, 2010) tells of a prison that was built centuries before to house all of society's undesirables. Now it is a place that no one ever leaves. Finn, a prisoner who was born in Incarceron, searches for a way to escape. Claudia, the warden's daughter, is also looking for a way out. They meet through the magic of a crystal key and try to help one another. Fever Crumb (Scholastic, 2010) is a prequel to one of Steampunk master Philip Reeve's earlier series, Hungry City Quartet. The protagonist, a young girl raised by the Order of Engineers, ventures into the perilous streets of London to find out who she is. While she searches, she is hunted down by villains who believe she is the last surviving member of a mutant race. Both of these stories have female protagonists, but they are suspenseful enough to interest any reader of speculative fiction.

\section{Enduring Issues with a New Twist}

Developmentally, adolescents are building a sense of identity and becoming more independent. This move away from family influences puts a greater emphasis on friendship, so social exclusion becomes a serious concern for many teens. The intense impact bullying has on victims is a very relevant topic for today's young adults. According to the Center for Disease Control's 2011 Youth Risk Behavior survey, 20 percent of high school students have been bullied on school property, 16 percent of high school students have been electronically bullied, and 16 percent had seriously contemplated suicide within the prior year. ${ }^{13}$ Erin Jade Lange's Butter (Bloomsbury USA Childrens, 2012) tells the story of an obese boy who plans to eat himself to death live on the Internet, and he becomes the victim of cyber bullies who cheer him on. Julie Anne Peters' By the Time You Read This I'll Be Dead (Hyperion/DBG, 2010) discusses the plans of a teen who has been bullied for years and who joins an Internet chat group that encourages suicide. In Jay Asher's Thirteen Reasons Why (Razorbill, 2007), a popular book with excellent reviews, a classmate sends the protagonist a voice recording saying there were thirteen people who contributed to her decision to commit suicide. He searches for the answer to why he is on the list.

The topic of death has been treated in new ways. One of the most creative and memorable aspects of Markus Zusak's The Book Thief (Knopf Books for Young Readers, 2006) was that it is was narrated by Death in a very engaging way. In Croak (Dutton Juvenile, 2009), by Gina Damico, a teenage girl is trained to take over the family business as the Grim Reaper. In Gayle Forman's If I Stay (Dutton Juvenile, 2009), Mia is in a coma after a horrible car accident that killed her family, and the reader is privy to her inner thoughts as she decides whether to live or die. In Every Day (Knopf Books for Young Readers, 2012), a unique treatment of the concept of the soul, David Levithan tells the story of a genderless sixteen-year-old soul, called A, who spends each day in a different body. The conflict arises when A falls in love with a girl and has to find ways to spend time with her. This is a unique look at gender, the search for identity, and love.

Teens with terminal illnesses, dubbed "sick lit" by the Daily Mail Online, ${ }^{14}$ are not new in adolescent literature; however, the storylines are getting more sophisticated. Libba Bray's Going Bovine (Delacorte Books for Young Readers, 2009) is a poignant, yet hilarious, look at a teenaged boy with Mad Cow Disease. John Green's The Fault in Our Stars (Dutton, 2012) is a deeply affecting book about two teens who are helping each other cope with cancer and their own imminent deaths. The female protagonist is fairly unlovable, yet the reader is engulfed in her struggle and the grief of those who surround her. Her male counterpart shows us that love can be strong and unyielding even when life is deeply unfair and both parties are flawed.

\section{New Contemporary Realistic Fiction}

Realistic fiction that deals with male perspectives on adolescence, or "Lad Lit," is not new but more of it is being published today..$^{15}$ Rob Thomas's Rats Saw God (Simon \& Schuster, 1996) and Stephen Chbosky's, The Perks of Being a Wallflower (Pocket Books, 1999) were notable realistic fiction texts published in the 1990's with male protagonists coping with unrequited love and coming of age. In the last few years, John Green has written several books, including An Abundance of Katherines (Dutton Juvenile, 2006), Looking for Alaska (Dutton Juvenile, 2005), and Paper Towns (Dutton Juvenile, 2008), about the romantic problems of teenage boys that have been extremely popular with both boys and girls. Three of YALSA's 2013 Top Ten Best Fiction for Young Adults are about males and relationships,${ }^{16}$ Jesse Andrews's Me and Earl and the Dying Girl (Amulet, 2012), Matthew Quick's Boy 21 (Little, Brown Book for Young Readers, 2012), and Benjamin Alire Saenz's Aristotle and Dante Discover the Secrets of the Universe (Simon \& Schuster Books for Young Readers, 2012). 


\section{READERS' ADVISORY}

\section{FINAL THOUGHTS}

If we subscribe to the belief that readers can be categorized by gender, we eliminate the opportunity to introduce teens to a plethora of wonderful materials that we assume will only interest one gender. The more we promote the notion of "boy books" or "girl books," the more we maintain a gender binary. It is this perception of gendered reading that perpetuates the idea that there is a "boy crisis" in literacy and that we must promote the reading of materials that will appeal to boys. The implication of this is that the reading interests of girls are unimportant because they will read anything.

We will continue to see males and females that corroborate the gendered reading model; however, if we pay attention, we will begin to notice all the variations within gender. Certainly, the popularity of Lad Lit is evidence that some boys do like fiction and realistic stories about relationships. The incredible demand for dystopian and post-apocalyptic fiction is a contradiction of the notion that most girls do not like action, conflict, or science fiction. What teens do want are engaging reads with relatable characters who face issues similar to those that concern adolescents today, artistic and creative writing, and new ways of thinking about the world.

\section{References}

1. David Bleich, "Gender Interests in Reading and Language," in Gender and Reading: Essays on Readers, Texts and Contexts, ed. Elizabeth A. Flynn and Patrocinio P. Schweickart (Baltimore, MD: Johns Hopkins University Press, 1986), 234-66; Merideth R. Cherland, Private Practices: Girls Reading Fiction and Constructing Identity (London; Bristol, PA: Taylor \& Francis, 1994); Linda K. Christian-Smith, Becoming a Woman Through Romance (New York; London: Routledge, 1990): Elaine Millard, Differently Literate: Boys, Girls and the Schooling of Literacy (London: RoutledgeFalmer, 1997); Janice A. Radway, Reading the Romance: Women, Patriarchy, and Popular Literature (Chapel Hill, NC: University of North Carolina Press, 1984).

2. Cherland, Private Practices.

3. Bobbie L. Hanley, "Gender and Reading: A Study of the Reading Response Patterns of Two Female and Two Male College Students" (PhD diss., University of Georgia, 1998), Dissertation Abstract International (UMI No. AAT 9836321).
4. Millard, Differently Literate.

5. Kristina Love and Julie Hamston, "Teenage Boys' Leisure Reading Dispositions: Juggling Male Youth Culture and Family Cultural Capital," Educational Review 55, no. 2 (2003):161-77; Michael Smith and Jeffrey D. Wilhelm, Reading Don't Fix No Chevys: Literacy in the Lives of Young Men (Portsmouth, NH: Heinmann, 2002).

6. Karen C. Beyard-Tyler and Howard J. Sullivan, "Adolescent Reading Preferences for Type of Theme and Sex of Character," Reading Research Quarterly 4, no. 1 (1980):104-20; Hanley, "Gender and Reading"; Nancy Prosenjak, "How Middle School Readers Respond as Gendered Readers of Gendered Texts" (PhD diss., Kent State University, 1997), Dissertation Abstract International, (UMI No. AAT 9802512); Smith \& Wilhelm, "Reading Don't Fix No Chevys."

7. Robert Loo and Karran Thorpe, "Attitudes toward Women's Roles in Society: A Replication after 20 Years," Sex Roles 39, no. 11/12 (1998): 903-12.

8. William Strauss and Neil Howe, Millennial Makeover: MySpace, YouTube, and the Future of American Politics (New Brunswick, NJ: Rutgers University Press, 2008).

9. “2013 Teens' Top Ten," Young Adult Library Services Association, accessed November 12, 2013, www.ala.org/yalsa/2013-teenstop-ten; Thomas P. Hebert and Alexander R. Pagnani, "Engaging Gifted Boys in New Literacies," Gifted Child Today 33, no. 3 (2010): 36-45.

10. "Popular YA Post Apocalyptic Books," Goodreads, accessed November 4, 2013, www.goodreads.com/shelf/show/ya-postapocalyptic?page $=2$.

11. Scott Westerfield, "Teenage Wastelands: How Dystopian YA Became Publishing's Next Big Thing," Tor.com (blog), April 15, 2011, www.tor.com/blogs/2011/04/teenage-wastelands-how-dystopian-ya-became-publishings-next-big-thing.

12. Daniel Kraus, "The 5th Wave," Booklist 109, no. 11 (2013): 51.

13. "2011 Youth Risk Behavior Survey," Centers for Disease Control and Prevention, www.cdc.gov/healthyyouth/yrbs/pdf.us_overview_yrbs.pdf.

14. Tanith Carey, "The 'Sick-Lit' Books Aimed at Children: It's a Disturbing Phenomenon. Tales of Teenage Cancer, Self-Harm and Suicide . .." Mail Online, Januar 3, 2013, www.dailymail.co.uk/ femail/article-2256356/The-sick-lit-books-aimed-children-Itsdisturbing-phenomenon-Tales-teenage-cancer-self-harm-suicidehtml?ito=feeds-newsxml.

15. Natalie Danford, "The Chick Lit Question," Publisher's Weekly 250, no. 42 (2003): 18-20.

16. "2013 Top Ten Best Fiction for Young Adults," Young Adult Library Services Association, accessed November 12, 2013, www. ala.org/yalsa/bfya2013/topten. 